\title{
A tüdő immunfiziológiája - útjelzők a terra incognita felé
}

\begin{abstract}
Balogh Péter dr. ${ }^{1,2}$
${ }^{1}$ Pécsi Tudományegyetem, Klinikai Központ, Immunológiai és Biotechnológiai Intézet, Pécs ${ }^{2}$ Pécsi Tudományegyetem, Szentágothai János Kutatóközpont, Nyirokszövet Fejlődésbiológiai Kutatócsoport, Pécs

A tüdő a benne lévő légutak és a légzőhám felületének kiterjedtsége, valamint a folyamatos napi gázcsere mennyisége miatt az emlősszervezetnek a környezeti antigének számára legnagyobb mértékben kitett közvetlen behatolási kapuja. A különböző antigénekkel szemben számos fizikai-mechanikai tisztulási folyamat, valamint helyi és szisztémás immunológiai védelmi mechanizmus együttesen biztosítja a légutak átjárhatóságát és a megfelelő gázcseréhez a légzőhám és a tüdő interstitialis összetevőinek szöveti integritását. A tüdő - veleszületett és adaptív immunológiai - védelmét ellátó molekuláris és sejtes résztvevőkre, ezáltal a légutak alapvető életfontosságú múködésének biztosítására vonatkozó ismereteink az utóbbi időben számos új megfigyeléssel bővültek, melyek felvetik a tüdő immunológiai szerveződésének egyedi szerkezeti és funkcionális specializációját. A jelen összefoglaló célja ezeknek az új eredményeknek a bemutatása, ezen keresztül a tüdőben zajló sokrétű immunológiai folyamatok fóbb jellemzőinek és a bennük részt vevő sejtes és molekuláris összetevőknek az áttekintése. Ezek részletesebb megismerése elősegítheti a légúti (köztük a SARS-CoV-2 általi) fertőzések után fellépő, helyi és szisztémás immunpatológiai események pontosabb megértését és a lehetséges terápiás eljárások kritikai értelmezését.
\end{abstract}

Orv Hetil. 2021; 162(29): 1147-1155.

Kulcsszavak: tüdő, immunitás, nyirokszövet, lymphocyta, szabályozás

\section{Immunophysiology of the lung - road signs to the terva incognita}

Due to the size of the surface area of airways and respiratory epithelium combined with the daily amount of continuous gas exchange, in mammalians the lung represents the most exposed organ serving as immediate entry port for airborne antigens. Together with several physicochemical clearance processes, both local and systemic immunological defense mechanisms ensure the passage of airways and the tissue integrity of respiratory epithelium and pulmonary interstitium necessary for the maintenance of gas exchange. Several recent observations concerning the molecular and cellular constituents of the pulmonary immunological defense have substantially broadened our knowledge of the maintenance of the vital functionality of airways, raising the unique specialization of the organization of pulmonary immune compartment. The purpose of the present review is to highlight the main findings on the complexity of pulmonary immunity, including the overview of the main characteristics of its cellular and molecular participants. Unrevealing these mechanisms may promote our understanding the local and systemic immunopathological processes occurring after airway infections (including SARS-CoV-2) and the critical assessment of potential therapeutic interventions.

Keywords: lung, immunity, lymphoid tissue, lymphocyte, regulation

Balogh P. [Immunophysiology of the lung - road signs to the terra incognita]. Orv Hetil. 2021; 162(29): 11471155 .

(Beérkezett: 2021. január 14.; elfogadva: 2021. január 30.)

\section{Rövidítések}

Ahr $=$ aril-hidrokarbon-receptor; APRIL $=($ a proliferation-inducing ligand) proliferációt indukáló ligand; BAFF $=\mathrm{B}$-sejtaktiváló faktor; BALT $=$ (bronchus/bronchiole associated lymphoid tissue) bronchus/bronchiolus asszociált nyirokszövet; $\beta 2 \mathrm{AR}=\beta 2$-adrenerg receptor; $\mathrm{CCL}=\mathrm{CC}$-típusú kemokin- ligand; CCR = CC-típusú kemokinreceptor; $\mathrm{CD}=$ (cluster of differentiation) differenciációs klaszter; CGRP $=$ (calcitonin gene-related peptide) kalcitoningén-rokon peptid; CLEC = (C-type lectin) C-típusú lektin; $\mathrm{CMC}=$ chronicus mucocutan candidiasis; $\mathrm{COPD}=($ chronic obstructive pulmonary disease $)$ chronicus obstruktív tüdőbetegség; CRP = C-reaktív protein; 
CSF1 = (colony-stimulating factor 1) kolóniastimuláló faktor- $1 ; \mathrm{CSFRl}=($ colony-stimulating factor 1 receptor $)$ a kolóniastimuláló faktor-1 receptora; $\mathrm{CXCL}=\mathrm{CXC}$-típusú kemokinligand; $\mathrm{CXCR}=\mathrm{CXC}$-típusú kemokinreceptor; $\mathrm{DAMP}=$ (danger-associated molecular pattern) veszélyasszociált molekuláris mintázat; FALC $=$ (fat-associated lymphoid clusters) zsírszövet-asszociált lymphoid klaszterek; FDC $=$ (follicular dendritic cell) follicularis dendritikus sejt; FGF $=$ (fibroblast growth factor) fibroblastnövekedési faktor; FRC = (fibroblastic reticular cell) reticularis fibroblast sejt; GM-CSF $=$ (granulocyte-monocyte colony-stimulating factor) granulocyta-monocyta kolónia stimuláló faktor; iBALT = (inducible bronchus/ bronchiole associated lymphoid tissue) indukálható bronchus/ bronchiolus asszociált nyirokszövet; ICOS $=$ (inducible T-cell co-stimulator) indukálható T-sejt-kostimulátor; ICOSL = (inducible T-cell co-stimulator ligand) az indukálható T-sejtkostimulátor ligandja; IFN = interferon; $\operatorname{IgG}=$ immunglobulin-G; IL = interleukin; ILC = (innate lymphoid cell $)$ veleszületett lymphoid sejt; IRA $=$ (innate response activator) veleszületett választ aktiváló; $\mathrm{LEC}=$ (lymphatic endothelial cell $)$ nyirokendothelsejt; LT $=$ lymphotoxin; Lti $=($ lymphoid tissue inducer $)$ nyirokszövet-indukáló sejt; MAdCAMl $=($ mucosal addressin cell adhesion molecule-1) nyálkahártya-addresszin sejtadhéziós molekula- 1 ; MALT $=($ mucosa-associated lymphoid tissue) nyálkahártya-asszociált nyirokszövet; $\mathrm{MBL}=$ mannózkötő lektin; M-CSF = (macrophage-colony stimulating factor) macrophagkolónia-stimuláló faktor; $\mathrm{MHC}=$ (major histocompatibility complex) fó hisztokompatibilitási komplex; NALT $=$ (nasal-associated lymphoid tissue $)$ orrüreg-asszociált nyirokszövet; NAM = (nerve-and-airway associated macrophage) ideg- és légútasszociált macrophag; $\mathrm{NK}=$ (natural killer) természetes ölősejt; $\mathrm{NMU}=$ neuromedin $\mathrm{U} ; \mathrm{NMURl}=$ neuromedin U-receptor-1; NOD = nukleotidkötő oligomerizációs domén; PAMP = (pathogen-associated molecular pattern) patogénasszociált molekuláris mintázat; PDLl = (programmed cell death ligand 1) programozott sejthalál ligand-1; $\mathrm{Pdpn}=$ podoplanin $; \mathrm{PG}=$ prosztaglandin $; \mathrm{PNAd}=$ perifériás nyirokcsomó-addresszin; PNEC = (pulmonary neuroendocrine cell) pulmonalis neuroendokrin sejt; $\operatorname{PPAR} \gamma=$ peroxiszómaproliferátor-aktivált receptor- $\gamma ; \mathrm{PRR}=($ pattern recognition receptor) mintázatfelismerő receptor; PTX3 = 3-as típusú pentraxin; RIG = retinsavindukált gén; RNS = ribonukleinsav; $\mathrm{ROR}=$ (retinoic acid receptor-related orphan receptor) retinsavreceptor-rokon árva receptor; SIP $=$ (sphingosine- 1 -phosphate) szfingozin-1-foszfát; SIPRI = (sphingosine- 1 -phosphate receptor-1) szfingozin-1-foszfát-receptor- 1 ; SAA = szérumamyloid-A; SAP = szérum-amyloid-P; SARS-CoV-2 = (severe acute respiratory syndrome coronavirus 2 ) súlyos akut légzőszervi szindrómát okozó koronavírus- 2 ; tbc = tuberkulózis; $\mathrm{T}_{\mathrm{CM}}=$ centrális memória-T-sejt; $\mathrm{TcR}=(\mathrm{T}$-cell receptor $) \mathrm{T}$-sejtreceptor; $\mathrm{T}_{\mathrm{EM}}=$ effektor memória-T-sejt $\mathrm{TGF} \beta=$ (transforming growth factor beta) transzformáló növekedési faktor-béta; TLR $=$ (toll-like receptor $)$ toll-szerü receptor; TNF $=$ tumornekrózis-faktor; Treg = regulátor $\mathrm{T}$-sejt; $\mathrm{T}_{\mathrm{RM}}=$ rezidens memória-T-sejt; TSLP = thymus stromalis lymphopoetin; VCAM = vascularis sejtadhéziós molekula; VEGF-C = (vascular endothelial growth factor $\mathrm{C}$ ) vascularis endothelialis növekedési faktor-C; VEGF-R = (vascular endothelial growth factor $\mathrm{R}$ ) vascularis endothelialis növekedési faktor-R; VIP = vasoactiv intestinalis polipeptid; VLA = (very late antigen $)$ nagyon késői antigén; VPAC $=$ a vasoactiv intestinalis peptid receptora

\section{A bronchoalveolaris rendszer szerveződése}

A tüdő és a légutak alapvető élettani funkciója a gázcsere, amely jelentős szerepet tölt be a szervezet pH-szabályozásában és vízháztartásában is. A légcsere a hatalmas felületet képező légzőhámon keresztül zajlik, amely közvetlen érintkezési felületet jelent az inhalált gázokkal, az azokkal együtt bejutó mikroorganizmusokkal és környezeti mikropartikulumokkal. Ezeknek a részecskéknek a bejutását és haladását számos mechanikai szűrő, nyákszekréciós és egyéb aktív eltávolítófolyamat korlátozza, illetve azok a hámbélésen átjutva különböző immunológiai folyamatokat válthatnak ki. Bár a tüdő és a légutak immunológiai jellemzőit a legtöbb immunológia-tankönyv és -monográfia rendszerint a nyálkahártyák immunológiájának részeként tárgyalja, a légutak immunológiai szerveződése és múködési jellemzői nagymértékben különböznek a béltraktus nyálkahártya-immunitásától, szükségessé téve a légutak (elsősorban a tüdő) immunfiziológiai áttekintését.

\section{A tüdő immunológiai vizsgálata - korlátok és akadályok}

A humán tüdő (túlnyomórészt leíró, jóval ritkábban kísérletes) immunológiai vizsgálata számos etikai és gyakorlatimódszertani akadályba ütközik. A mintavétel szinte kivétel nélkül daganatos állapot miatt végzett mútéti vagy biopsziás anyagokra vagy transzplantáció miatt donorokból eltávolított mintákra korlátozódik. A szintén súlyos kórelváltozások során végzett bronchoalveolaris lavage révén nyert vizsgálati minta csak a légutak felületéról levált sejtek vizsgálatára alkalmas, amelyek jellemzői eltérők lehetnek a tüdő interstitiumában tartózkodó sejtekéitől, valamint a normál egészséges kontroll állapottól.

A tüdő fiziológiás immunológiai folyamataira vonatkozó ismereteink elsősorban egereken végzett in vivo kísérletekből származnak. Ezek értékelésekor figyelembe kell venni az emberi és az egértüdő alapvető szerkezeti és funkcionális eltéréseit: az egértüdő a humántól eltérően egy bal oldali és négy jobb oldali lebenyből áll, a légutakat fedő hámsejtösszetétel is különbözik, és a légzésfrekvencia is többszöröse a humánénak.

\section{A légutak veleszületett immunológiai védelmének szolúbilis faktorai}

A bronchialis és alveolaris hámsejtek elsődleges mechanikus védelmét a kehelysejtek által képzett nyák, valamint a mucociliaris transzport biztosítja, melyben membránkötött (MUC1, MUC4, MUC16) és szekretált (MUC5AC és MUC5B) mucinok vesznek részt. Ezek a mucinok a légúti nyák viszkoelasztikus szabályozásán túlmenően gélképző tulajdonságaik révén részt vesznek a közvetlen antibakteriális védekezésben, és elősegítik a pulmonalis macrophagok aktiválódását. Termelődésük fokozható 
akár patogénasszociált (PAMP) vagy veszélyasszociált (DAMP) mintázatok felismerésen keresztül vagy citokinek (elsősorban IL-1ß és IL-17) hatására. Emellett számos antimikrobiális faktor helyi képzése járul hozzá a hatékony nyálkahártya-védelemhez, amelyek nagy részben a hámot ért mikrobiális vagy mikropartikulumok általi károsítás után a mintázatfelismerő receptorokon (PRR) keresztül kerülnek felismerésre [1].

A citoplazmában NOD/RIG receptorok, valamint sejtfelszíni PRR-ok, 'scavenger' receptorok, toll-szerü receptorok (TLR) stb. mellett az utóbbi időben egyre több szekretált PRR (sPRR) szerepére derült fény [2]. Ezek egy részét a légúti hámsejtek termelik, de ismerünk a tüdőben előforduló macrophag-, granulocyta-, dendritikussejt- és T-sejt-eredetű sPRR-molekulákat is. A képzett faktorok agglutináció, neutralizáció által, komplementaktivációhoz kapcsolt vagy attól független opszonizáció révén segítik elő a kórokozók eliminálását, és befolyásolják a helyi gyulladás lefolyását. Ezek alapján megkülönböztethetünk nem komplementaktiváló sPRR(például szérum-amyloid-A [SAA]) és komplementaktiváló sPRR- (például pentraxin-3 [PTX3], C-reaktív protein $[\mathrm{CRP}]$, mannózkötő lektin [MBL] és fikolinok) összetevőket, valamint önmagukat a különböző komplementkomponenseket, elsősorban a C3-faktort.

A hosszú láncú oktamer szerkezetû PTX3 helyi (elsősorban gyulladásos leukocyták, bronchialis és alveolaris hámsejtek, valamint peribronchialis simaizomsejtek általi) képződése jóval gyorsabb, mint a CRP és a szérumamyloid-P (SAP) rövid pentraxinok IL-6 hatására bekövetkező termelése a májban. A PTX3 ligandjai közé tartozik a Klebsiella pneumoniae protein A sejtfalkomponense, illetve kölcsönhatásban áll a komplement klasszikus és alternatív összetevőkkel, valamint különböző Fc $\gamma$ receptorokkal, az FGF2-vel és a P-szelektinnel is. PTX3 hatására egerekben erősödik az antimikrobiális ellenállás, ugyanakkor fokozott mennyisége szintén megfigyelhetó asztmás gyermekek köpetében, illetve tüdőrákban szenvedők szérumában. Hiánya elősegítheti súlyos tüdőaspergillosis kialakulását (például csontvelő-transzplantációt követően) [3], ugyanakkor emelkedett mennyisége szintén a tüdőaspergillosis kórjelzője lehet [4].

A Streptococcus pneumoniae sejtfalának C-poliszacharidját $\mathrm{Ca}^{++}$-függő módon precipitáló CRP képződését májsejtekben az IL-6 indukálja, a képzett CRP penta/ dekamer formában található a szérumban. A CRP a bakteriális ligandok megkötése mellett az apoptotikus sejtek membránján felszabaduló foszforil-kolin felismerésén keresztül ezen sejtek eltakarításában vesz részt, valamint hiszton és egyéb nukleoproteinek és extracelluláris mátrix-összetevők megkötésével szisztémás autoimmun megbetegedések kialakulásában játszhat szerepet [5].

A humán mannóz/mannán kötő lektin (MBL) a komplementrendszer legősibb aktivációs útvonalának elindítója. Egészséges körülmények között a légutakban nem fordul elő, gyulladás hatására viszont kimutatható. A MBL a mikrobiális patogének opszonizálása mellett az elpusztult, leváló alveolaris hámsejtek eltávolításában is fontos szerepet játszik. Ennek során a célsejthez kapcsolódott MBL (a kalretikulin közvetítésével és a CD91molekula révén) elősegíti ezeknek a károsodott sejteknek az alveolaris macrophagok általi eltávolítását $[6,7]$.

\section{A légutak fontosabb phagocyta-alcsoportjai}

Más szövetekhez hasonlóan a tüdőmacrophagok is szövetspecifikus rezidens myeloid sejtek, melyek elsődleges funkciója a parenchyma védelme, szöveti korrekciójának elősegítése és a homeosztázis fenntartása. Fejlődésükhöz a kolóniastimuláló faktor-1 receptora (CSFRl) szükséges, amely a macrophagkolónia-stimuláló faktor (M-CSF) és az IL-34-ligandok megkötését követően aktiválja a macrophagdifferenciálódási programot. A tüdő macrophagjait eredetük, elhelyezkedésük, funkcióik és sejtfelszíni markereik alapján két fó alcsoportra osztjuk [8].

Az alveolaris macrophagok a nevüknek megfelelően az alveolusok hámsejtjei között, illetve az alveolaris lumen felületén helyezkednek el; feladatuk a légutakon keresztül bejutott mikrobák, elpusztult sejtek és egyéb mikropartikulumok eltávolítása, valamint a surfactant lebontása. Fejlődésük az embryonalis korban a szikzacskó myeloid prekurzoraiból a II. típusú pneumocyták által termelt GM-CSF és az autológ TGFß hatására indukált peroxiszómaproliferátor-aktivált receptor- $\gamma \quad(\operatorname{PPAR} \gamma)$ transzkripciós faktor aktiválódásától függ [9]. Az embryo fejlődése és a postnatalis kor idején bekövetkező szervnövekedés során az alveolaris macrophagprekurzorok önmegújító osztódás révén töltik ki az alveolaris tartományban a számukra rendelkezésre álló teret, amihez idősebb egyedekben a csontvelői eredetû prekurzorok is részben hozzájárulhatnak [10].

A kiérett alveolaris macrophagok a születést követően jelennek meg a tüdőben, differenciálódásuk utolsó szakaszát a légzés során az oxigénexpozíció segíti elő. Diagnosztikus lavage során nyert mintában elsősorban ezeknek a felületi macrophagoknak egy része válik vizsgálhatóvá. Az alveolaris macrophagok gyulladásgátló funkciókat látnak el, amfiregulintermelésükkel a károsodott tüdőhám regenerációját segítik elő [11].

Az embryonalis szikzacskó eredetû alveolaris macrophagok újdonképződése helyi önmegújítás eredménye. Kiterjedt károsítás (például irradiálás) során ugyanakkor ez a sejtforrás elégtelen, és az elpusztult sejteket a csontvelői monocyták pótolják, melyek között egyaránt kialakulhatnak proinflammatoricus és regulátor/gátló hatású sejtek is. Nyugvó körülmények között az alveolaris macrophagokat a hámsejtek $\alpha \mathrm{v} \beta 6$-integrinjéhez kapcsolódó TGFß és CD200-molekula gátlás alatt tartja, ami a hámsejtek pusztulása után a macrophagok IFN $\alpha$ és IFNß-termeléséhez vezet. A macrophag- és dendritikus sejtek PRR-szenzorokon keresztüli patogénfelismerése IL-12 és IL-23 részvételével általában Thl-típusú választ vált ki, míg a phagocytasejtek, patogének, allergének és toxinok általi szövetsérülés, valamint az interstiti- 
alis hízósejtekből felszabadult proteázok és egyéb szöveti mediátorok a Th2-típusú immunválasz kialakításáért felelősek, amelyben az IL-25 és az IL-33 aktivitása a meghatározó [12].

Az alveolusokat elválasztó septumok az interalveolaris Kohn-pórusokon keresztül átjárhatók [13], amelyek a bronchioloalveolaris Lambert-csatornákkal és az interbronchiolaris Martin-csatornákkal együtt a tüdő kollaterális légáramlását biztosítják. Ezek a járatok elősegíthetik a tüdőbe kerülő partikulumok és fertőző ágensek terjedését, ugyanakkor az itt elhelyezkedő alveolaris macrophagok számára ezek a nyílások haladási útvonalakat is nyújtanak [14].

Az interstitialis macrophagok a tüdőhám és a kapillárisok közötti térben helyezkednek el, a csontvelői monocytákból fejlődnek, homeosztázisuk is a folyamatos csontvelői monocyta-utánpótlásból történik. Különböző markerexpressziós mintázatuk alapján emberben és egérben egyaránt több alcsoportjukat írták le, amelyeket az utóbbi időben végzett egysejtes (single cell) RNS-szekvenáló eljárások az egyes alcsoportok különböző kemokintermelési jellemzői alapján tovább bővítettek [12].

Az interstitialis macrophagok egyik alcsoportja perineuralisan helyezkedik el, és hatékony antigénprezentáló sejt. Ezzel szemben a perivascularis komplementer alcsoport elsősorban a sebgyógyulásban és a szöveti regenerációban vesz részt, és szabályozza a gyulladásos sejtes infiltrációt is [15]. Az ideg- és légútasszociált macrophagok (nerve-and-airway associated macrophage - NAM) szikhólyag-eredetűek, CSFl-függő módon alakulnak ki, és érésük nem függ a GM-CSF-től és a CCR2+-monocytáktól. Influenzavírus és poli(I:C) (TLR3-ligand) hatására intenzív osztódást mutattak. Elsődleges szerepük feltehetőleg a fokozott gyulladás gátlása, hiányukban fokozott gyulladásoscitokin-termelés és veleszületett immunsejt-infiltráció figyelhető meg [16].

\section{A szenzor- és effektorsejtek összekapcsolásának közvetítői - a veleszületett lymphoid sejtek szerepe a tüdő immunvédekezésében}

Az elmúlt évtized egyik legfontosabb koncepcionális elörelépése a veleszületett lymphoid sejtek (ILC) alcsoportjainak azonosítása és funkcionális jellemzőinek megismerése volt. Ezek a lymphoid típusú fehérvérsejtek a T- és B-sejtekkel ellentétben nem hordoznak antigénreceptorokat, múködésük viszont sok tekintetben (így a differenciálódásukat szabályozó transzkripciós faktorok, illetve stimuláció során az általuk termelt citokinek) a T-lymphocyták jellemzőit tükrözi. Ennek megfelelően a citotoxikus T-sejtek analógjának az NK-sejtek, míg az ILC1 a Thl (T-bet-függó és IFN $\gamma$-termelö), az ILC2 a Th2 (GATA3- és ROR $\alpha$-függő és IL-4/5/9-termelő), az ILC3 a Th17 (ROR $\gamma$-függő és IL-17-, valamint IL22 -termelő) 'helper' T-sejtek alcsoportjának feleltethető meg [17]. Az NK-sejtek a vírusfertőzéssel szembeni védelemben és a daganateliminációban, az ILCl-sejtek az intracelluláris patogénfertőzéssel szembeni védelemben, az ILC2-sejtek a parazitákkal szembeni védelemben és a szöveti regenerációban, míg az ILC3-sejtek az extracelluláris baktériumokkal szembeni védekezésben vesznek részt. Ugyanehhez a csoporthoz tartozik az embryonalis nyirokszövet-indukcióért felelős Lti- (lymphoid tissue inducer) alcsoport. A regulátor T-sejtekhez (Treg) hasonló ILCreg-alcsoport az immunválaszok leállításában játszik szerepet, feltehetőleg a proinflammatoricus ILC1- és ILC3-alcsoport IL-10 közvetítette gátlásával, valamint önmaga TGFß1 autokrin képzésén keresztüli fenntartásával [17].

Az NK-sejtek a nem lymphoid szövetek közül a legmagasabb arányban a tüdőben fordulnak elő (az összlymphoidsejt kb. 10-20\%-a), amelyek a tüdóhám- és alveolaris macrophagok hatásására gátolt állapotban vannak. Légúti vírusfertőzés hatására a gátlás hámdestrukció miatti megszúnésével vírusdózistól függően protektív, illetve szövetdestruáló hatást fejthetnek ki [18].

Az ILC-sejtek fooként a felszíneken (bél, bőr és tüdő) helyezkednek el, ezek közül az ILC2-sejtek emellett a mandulákban, a májban, a vesében, a thymusban és a zsírszövetekben is kimutathatók. A perifériás vérben csak minimális számban vannak jelen, ami megerősíti ezeknek a sejteknek a szövetrezidens jellegét. Az ILC2-populáció több alcsoportot tartalmaz, melyek ILC3 típusúvá is átalakulhatnak, illetve az ILC3-populáción belül is több alcsoport különíthető el [17].

A tüdőben a legnagyobb számban az ILC2 típusú sejtek találhatók, melyek egerekben a hámsejtek környezetében helyezkednek el. Feltehetőleg a közös ILC-prekurzorokból a tüdő mikrokörnyezetének hatására nyerik el érett állapotukat, majd gyulladások során (fóként a tüdőhám-, endothel-, T-sejtek, ILC3-, illetve hízósejtek, eosinophil sejtek és egyéb myeloid sejtek) által képzett IL-25, IL-33 és TSLP (thymus stromalis lymphopoetin) „alarmin” faktorok hatására aktiválódnak. Ugyanakkor IL-4, IL-5, IL-9, IL-13 és egyéb citokinek termelésével ugyanezekre a sejtekre visszahatva komplex szabályzóköröket alakítanak ki [19]. Az ILC2 tüdőben való felhalmozódásában a Th2-sejt-eredetû IL-4 és IL-13 fontos szerepet tölt be féregfertőzés során. Ez egyidejúleg elősegíti az ILC2-sejtek felszínén az MHCII kifejeződését is, ezáltal erősítve a Th2- és ILC2-sejtek közötti antigénspecifikus kommunikációt [20].

Az ILC2 számára fontos korai szignált jelent a prosztaglandin (PG) D2 felismerése, amely az ILC2-sejtek alarminreceptorainak kifejeződését fokozza. Ezzel ellentétes a PGE2, amely az ILC2-sejtek citokintermelésének csökkenéséhez vezet. Az ILC2 további fontos lipidszenzora a PPAR $\gamma$, mely egyrészt fokozza az IL-33 ILC2aktiváló hatását, másrészt pozitív visszacsatolás részeként IL-33 hatására fokozódik a PPAR $\gamma$ termelődése. Ezen utóbbi szükséges az ILC2 aktiválódása során az IL-5 és 
IL-13 képzéséhez, gátlása csökkenti az ILC2-sejtek részvételével zajló akut légúti gyulladásokat [21].

Az ILC2 helyi sejtaktiválásának szabályozásában közvetlen sejt-sejt kontaktusok közül az OX40:OX40L, ICOS:ICOSL kötődés aktiváló, míg a PDLl megkötése gátló hatást fejt ki [22].

A tüdő hám-ILC2 interakció fontos kiegészítője a pulmonalis innervatio. Az ILC2-sejteket serkentő neuropeptidek közé tartozik a VIP, amely a VIP-receptorokon (VPACl és VPAC2) keresztül stimulálja az ILC2sejteket, míg a VPAC2-antagonista kezelés az ILC2 általi IL-13-termelést és az IL-33-receptor kifejeződését csökkenti. Szintén serkentő hatású a kolinerg neuronok által termelt neuromedin U (NMU), amely a NMURl receptoron keresztül fejti ki hatását [23]. Hasonlóképpen neuronalis hatást fejt ki a pulmonalis neuroendokrin sejt (PNEC) által termel kalcitoningén-rokon peptid (CGRP), amely IL-25, NMU és IL-33 együttes jelenlétében fokozta az ILC2-sejtek IL-5- és IL-6-termelését [24], ugyanakkor gátolta az IL-13-képzését és az ILC2sejtek osztódását. A CGRP hiánya elősegítette az ILC2sejtek aktiválódását, ezáltal fokozva a pulmonalis féregfertőzéssel szembeni immunválasz hatékonyságát [25].

A fentiekkel szemben a $\beta 2$-adrenerg receptorokon ( $\beta 2 \mathrm{AR})$ keresztüli stimulusok gátolják az ILC2-sejtek aktivitását és számát, míg a $32 \mathrm{AR}$-hiányos egerekben fokozott ILC2-proliferációt és eróteljes, 2-es típusú gyulladásos reakciót figyeltek meg [26]. Emellett az A-vitaminból képződő retinsav hatására ILC2-ILCreg átalakulást igazoltak, és szintén gyulladáscsökkentő hatást figyeltek meg a tesztoszteron esetében $[27,28]$.

\section{A légutak adaptív nyirokszövetei és jellemzőik}

A fentiekben bemutatott, veleszületett védelmi folyamatok kialakulásához nem szükséges komplex szerkezetű szekunder nyirokszövetek jelenléte, ugyanakkor az antigénreceptorok specifikus ligand-felismerésén alapuló adaptív immunválaszok a T-és B-sejtek kölcsönhatására specializálódott strukturált perifériás nyirokszövetekben zajlanak.

A légutak mentén különböző szerkezetű immunkompetens szöveteket figyelhetünk meg, amelyek a helyi adaptív immunválaszok kialakulásának szövetspecifikus helyszínei. Emberben a nasopharyngealis és oropharyngealis régióban elhelyezkedő adenoidok és mandulák együttesen alkotják a Waldeyer-gyưrüt, míg egérben a hasonló funkciójú nyirokszövetek a kemény szájpad felett, az orrjárat mentén húzódó, gyöngyfüzérszerű nasalis nyirokszövetek (NALT).

\section{A bronchusasszociált nyirokszöpetek (BALT) fejlödési jellemzôi}

A béltraktussal ellentétben a tüdőben egészséges körülmények között nincsenek strukturált nyirokszövetek, csak a bronchus (általában az elágazásoknál) hámrétege alatt perivascularis elhelyezkedésú indukálható bronchus / bronchiolus asszociált nyirokszövet (iBALT) található, változatos szerkezeti összetételben [29]. Az iBALT-ra általában jellemző az elkülönült, B-sejt-dús nyiroktüszők és T-sejtes zóna megléte, valamint a nyirokcsomókra jellemző magas endothelialis venulák megjelenése, de előfordulnak diffúz kevert (nem elkülönült) formában is.

Az iBALT kialakulását elsősorban egerekben vizsgálták, ugyanakkor számos humán kórképben is leírták ezek jelenlétét. Az iBALT megjelenése jellemző COPD-ben, részecskeexpozíciót (szilikátok, dohányzás) és fertőzéseket követően, chronicus gyulladásokban és autoimmun betegségekben (Sjögren-szindróma, rheumatoid arthritis), allograftrejekció során, allergiás és asztmás betegekben és tüdőtumorokban. Az iBALT-struktúrák a nem programozott tercier/ectopiás nyirokszövetek közé tartoznak. Szintén gyulladások következtében (újszülöttekben elsősorban cytomegalovirus-fertőzés után) myeloid sejtekből és CD8+ T-sejtekből álló nodularis gyulladásos gócok jelenhetnek meg, míg tbc-fertőzés hatására granulomák alakulnak ki; az utóbbiak Mycobacterium tuberculosis fertőzött macrophagok körül csoportosuló T- és B-sejtekből állnak [30].

A fenti képletek közül a bronchialis hám bazális része alatti iBALT-struktúrák hasonlítanak a leginkább az adaptív immunválaszokban részt vevő szekunder nyirokszövetekre. Így elkülönült T- és B-sejtes zónát (az utóbbiban esetenként csíracentrumot), ezekkel párhuzamosan szegregálódó, CCL21-kemokint termelő reticularis fibroblast (FRC-) és CXCL13-termelő follicularis dendritikus sejt (FDC-) hálózatokat és nyirokereket tartalmaznak [30]. Bár hagyományosan a nyálkahártya-asszociált nyirokszövetrendszer (MALT) tagjának tekintjük, az iBALT a magas endothelialis venula felszínén nem a bélnyálkahártyára jellemző MAdCAMI addresszin, hanem a nyirokcsomókra jellemző PNAd addresszin mutatható ki . Míg a bél lamina propria nem tartalmaz afferens nyirokkapillárisokat, az iBALT esetében az itt futó nyirokerek egyaránt lehetnek efferens és afferens nyirokerek. Az efferens szakaszok az iBALT fehérvérsejtjeinek a keringésbe való visszajutását, valamint a drenáló mediastinalis nyirokcsomókban az immunválasz gyorsabb fellépését segítik, míg az afferens nyirokerek a távolabbi tüdőszakaszok felőli helyi antigénfelvételben vesznek részt. Ennek megfelelően - a bél nyirokszöveti territóriumaitól eltérően - az iBALT-képletekre az M-sejtek hiánya jellemző [29, 30].

Az utóbbi időben a nyirokkeringés megváltozásának az iBALT kialakulásában betöltött szerepére is fény derült. Egerekben a peribronchialis és perivascularis nyirokerekben a normál-nyirokáramlást a mellüregi nyomásváltozás irányítja. A nyirokkapillárisok kialakulását a nyirokendothelsejteken (LEC) kifejeződő podoplanin segíti elő, amely a thrombocytafelületi CLEC2 megkötésével irányítja a nyirokkapillárisok szerkezeti és funkcionális érését. Ennek a ligandfelismerésnek az elmaradása 
- a nyirokkapillárisok defektusán keresztül - CLEC2-hiányos egérben spontán iBALT-megjelenéshez vezet [31].

Egerekben ezek a képletek a kiváltó faktor jellegzetességeitől függően többféle módon jöhetnek létre. Antigénspecifikus adaptív immunválaszokat követően tartósan perzisztálnak, és ezáltal más antigénekkel szembeni humorális immunválaszokhoz is hozzájárulhatnak. Emellett érdekes módon az iBALT és a NALT is saját programozottságot mutat, illetve mindkettő számos jellemzőben eltér a bélasszociált nyirokszövetek fejlődési eseményeitől [32]. Az 1. táblázat ezeket a morfogenetikai jellemzőket hasonlítja össze.

Az iBALT fejlődése több, egymást részben átfedő útvonalon és sejtes kölcsönhatások során történhet. Általában jellemző, hogy újszülött- és fiatalkorban jóval nagyobb mértékben váltható ki iBALT-képződés, ami esetleg az immunológiailag naiv egyed fokozott patogénexpozíciójával függhet össze, de szerepe lehet benne a Treg-sejtek relatív hiányának, valamint az iBALT-képződésben fontos granulocytaválasznak is gyulladások során $[30,32]$.

Az iBALT-képződés elindításáért számos myeloid sejt lehet felelős. Így a dendritikus sejtek lymphotoxin (LT)termelésük, míg antigénprezentáló sejtként a T-sejtek BAFF-termelésük révén a B-sejt aktiválását segítik elő. Emellett IL-12-termeléssel a $\gamma \delta T$-sejteket, IL-23- és IL-6-termelésükkel pedig az ILC3-sejteket stimulálják. Ezek a különböző lymphoid sejtek a kulcsfontosságú IL-17 képzésével segítik elő neutrophil granulocyták és monocyták megjelenését [32]. Az IL-17 jelenléte előse-

1. táblázat |A bél- és légútasszociált nyirokszövetek fejlődési determinánsai

\begin{tabular}{|c|c|c|c|}
\hline $\begin{array}{l}\text { Sejtes /molekuláris } \\
\text { morfogén }\end{array}$ & $\begin{array}{l}\text { Peyer-plakk } \\
\text { (praenatalis) }\end{array}$ & NALT & iBALT \\
\hline $\begin{array}{l}\text { ROR } \gamma t \\
\text { (Lti-és ILC3-alcsoport) }\end{array}$ & + & - & - \\
\hline Id2 (NK-sejt és minden ILC) & + & + & - \\
\hline $\begin{array}{l}\text { Myeloid sejtek (CDIIc DC, } \\
\text { neutrophil granulocyták, alveolaris } \\
\text { macrophagok) }\end{array}$ & - & - & + \\
\hline$I L-7$ & + & - & - \\
\hline$I L-17$ & - & - & $+{ }^{*}$ \\
\hline CXCL13 & + & - & $-\#$ \\
\hline$L T \alpha$ & + & - & -\# \\
\hline
\end{tabular}

A (+) jel az adott faktortól való függést, a (-) ennek hiányát jelzi.

*Indukcióhoz szükséges, fenntartáshoz nem.

"Indukcióhoz nem szükséges, fenntartáshoz igen.

$\mathrm{CD}=$ differenciációs klaszter; $\mathrm{CXCL}=$ CXC-típusú kemokinligand; DC = dendritikus sejt; iBALT = indukálható bronchus/bronchiolus asszociált nyirokszövet; IL = interleukin; ILC = veleszületett lymphoid sejt; LT = lymphotoxin; Lti = nyirokszövet-indukáló sejt; NALT = orrüreg-asszociált nyirokszövet; $\mathrm{NK}=$ természetes ölősejt; $\mathrm{ROR}=$ retinsavreceptor-rokon árva receptor gíti a stromalis sejtek aktiválódását és FDC-k érését, melyek CXCL13-termelésük révén fokozhatják a B-sejtes akkumulációt; ezt a szintén neutrophil és eosinophil granulocyták által termelt BAFF-analóg APRIL is fokozza [30]. A felhalmozódó B-sejtek LT/TNF termelésükkel elősegítik és stabilizálják az FDC-hálózatot, ezáltal az akut gyulladásra jellemző korai, „diffúz” típusú B-sejtes akkumuláció „konstitutív” típusúvá alakul.

Az iBALT nem haematopoeticus alapállomány jelentékeny része egérben a $\mathrm{FAP} \alpha^{+}$(fibroblastaktivációs protein), $\mathrm{VCAMl}^{+}$és $\mathrm{CXCLl}^{+}$mesenchymalis sejtekből differenciálódik; egy részükből az iBALT-nyiroktüsző $\mathrm{CXCL} 3^{+} / \mathrm{CD} 35^{+}$FDC-hálózata alakul ki, míg a Pseudomonas aeruginosa által kiváltott iBALT-nyiroktüszővariáns FDC az előzőtől eltérően CXCL13-/CD35-, viszont a (nyirokendothelre jellemző) podoplanin (Pdpn $)^{+}$ és CXCL12+ [33].

Az iBALT indukciójában szereplő IL-17 a CCL19/21 T-sejtes kemoattraktánsok termelődését is fokozza [34]. Ez az iBALT-B-sejtek által nyújtott LT-ligandokkal együtt elősegíti a T-zónai FRC-hálózat kialakulását, amely IL7-termelése révén a helyi T-sejt-túlélést támogatja. Emellett a lymphoid sejtek megtelepedése elősegíti a posztkapilláris venulák magas endothelialis venula típusú átalakulását, míg a macrophagok és elsősorban a T-sejtes zónában megtelepedő egyéb myeloid sejtek a VEGF-Ctermelésükkel VEGFR2/VEGFR3 szignalizáción keresztül a nyirokerek bimbózását váltják ki; az így kialakult nyirokerek a fertőzés megszúnése után is fennmaradnak [30].

Szekunder nyirokszövetekkel nem rendelkező egerekben (LT hiányában nyirokcsomó és Peyer-plakk nélküli egerek lépeltávolítás után) kimutatták, hogy az elsőként alkalmazott légúti stimulust követően a légutaikban iBALT-ot tartalmazó egerek hatékonyabb antivirális és antibakteriális immunválasszal és memóriaképződéssel reagáltak [34]. Ugyanakkor a bronchus/bronchiolus fal mentén képződő iBALT jelenléte a COPD súlyosabb állapotára jellemző. Miután iBALT-ban kimutathatók a különböző autoantitest-termelő B-sejtek ( rossz” iBALT), viszont az adaptív immunválasz helyi fókuszálásával jelenlétük megelőzi a diffúz tüdőparenchyma-károsodást és tumorprogressziót („jó” iBALT), ezeknek a struktúráknak a szerepe az adott kórkép függvényében feltehetőleg eltérő [35].

\section{A légutak járulékos B-sejtes védelme: BI B-sejtek, veleszületett választ aktiváló (IRA) B-sejtek}

A fentiekben részletezett iBALT-képletek elsősorban a csontvelői eredetú B2-sejtek részvételével alakulnak ki. Emellett az utóbbi időben a légutak B-sejtes immunológiai szerveződésének újabb elemeként került felismerésre a pleuralis térben elhelyezkedő, embryonalis haematopoeticus őssejtekből differenciálódó Bl - [36] sejtek szerepe is. Egérben a Bl-sejtek immunológiai tulajdonsága- 
inak tanulmányozására a jóval könnyebben kinyerhető peritonealis B-sejteket vizsgálják, ugyanakkor ismert, hogy a Bl-sejtek (feltehetően a rekeszizmon keresztül) eljuthatnak a pleuralis térbe is [37].

A szintén közeli anatómiai elhelyezkedésú mediastinalis és pericardialis zsírszövetben leírt leukocytakongregátumokban (FALC - fat-associated lymphoid cluster [38]) elhelyezkedő Bl-sejtek is fontos szerepet töltenek be a légutakon keresztül bejutott élősködókkel és allergénekkel szembeni, IgM közvetítette immunválaszokban. Fertőzést követően a FALC stromasejtjei IL-33-citokint termelnek, amely az itt elhelyezkedő, ILC2-típusú sejtek IL-5 termelését váltja ki [39].

Az ILC2-sejtek által képzett IL-5 a B-sejtek helyi antitesttermelő plazmasejtté történő differenciálódását segíti elö, amelyben az IL-17 is fontos szerepet játszik. Ennek termelésében a pulmonalis $\gamma \delta \mathrm{T}$-sejtek vesznek részt. Emellett az I. típusú interferon a Bl-sejtek CDllb-integrinmolekulájának nagy affinitású konformációváltását váltja ki, ezáltal fokozva az aktivált Bl-sejteknek a mediastinalis nyirokcsomóba irányuló megtelepedését [40].

A helyi B-sejt-aktiváció további disszeminálódását segíti elő, hogy az általában nem recirkuláló peritonealis Bla-sejtek különböző TLR-ligandok hatására a vérkeringésbe lépő, autokrin GM-CSF-termelő és attól veleszületett választ aktiváló (IRA) B-sejtekké alakulhatnak. Az IRA B-sejtek elősegítik a bakteriális clearance folyamatát, és gátolják a szepszis során fellépő citokinvihar kialakulását [41], valamint polireaktív IgM-termelésükön keresztül is fontos szerepet tölthetnek be a légutak korai, antitest közvetítette immunológiai védelmében [42].

Egérben a képződött iBALT-memória-B-sejtek csökkent CD62L-kifejeződése és fokozott CXCR3-termelése (CD62L $\downarrow$ CXCR3 $\uparrow$ ) ezen sejtek fokozott rezidens pulmonalis felhalmozódását és szisztémás recirkulációjának csökkenését jelzi. Ezt követően az antigénspecifikus $\mathrm{IgG}^{+}$-memória-B-sejtek egy része a mediastinalis nyirokcsomókba és a lépbe jut, ahol tartósan fennmarad. Így a légúti immunizálást/fertőzést követően egyidejűleg képződnek tüdőrezidens (CD62L $\downarrow / C X C R 3 \uparrow$ ) és szekunder nyirokszövet-rezidens memória-B-sejtek [43].

\section{A T-sejtek szerepe a tüdö immunológiai védelmében: $\gamma \delta T$-sejtek, Th17 CD4+ T-sejtek, $C D 8^{+}$T-sejtek és alcsoportjaik}

Az adaptív immunválaszok során a T-sejtek központi szerepet töltenek be az antigénspecifikus felismerést követően a B-sejtek aktiválásában, a citotoxikus folyamatok elősegítésében, a fertőzött sejtek elpusztításában, valamint az antigénprezentáló sejtek aktivitásának szabályozásában és az immunológiai memória kialakításában.

A tüdőben előforduló T-sejtek jelentékeny része CD4/CD8 kettősen negatív sejt, melyek a pulmonalis összlymphocyta-állomány hozzávetőleg 10-20\%-át teszik ki. Ezeknek a sejteknek a többsége a születés utáni újszülöttkorban telepszik meg a tüdőben, ahol a viszonylag kis számú, meghatározott $\gamma \delta$-lánc-összetételű TcR-t hordozó T-sejt-klón dominanciája jellemző. Bakteriális fertőzésben az IL-1 $\beta /$ IL-23 által stimulált $\gamma \delta$ T-sejtek az IL-17A korai termelésével fontos szerepet töltenek be a neutrophil granulocyták felszaporodását és phagocytosisát elősegítő G-CSF és MIP2-citokinek indukciójában. Emellett a $\gamma \delta$ T-sejtek fokozott TNF- és IFN $\gamma$-termelése elősegíti a pulmonalis dendritikus sejtek és alveolaris macrophagok aktiválódását is [44]. Vírusfertőzések során a $\gamma \delta$ T-sejtek szintén proinflammatoricus és antivirális aktivitást mutattak, amelyben az IL-22 fokozta, míg az I. típusú interferon csökkentette az IL-17A-termelő $\gamma \delta$ T-sejtek antibakteriális hatásait. M. tuberculosis esetén az elsődleges helyi aktiváló esemény a fertőzött dendritikus sejtek megnövekedett IL-23 termelése, ami fokozza a $\gamma \delta$ T-sejtek általi korai IL-17A-képződést, valamint a granulomakialakulást. Érdekes módon tbc-s betegek vérében emelkedett az IL-17-termelő $\gamma \delta$ T-sejtek, és csökkent az IFN $\gamma$-termelő $\gamma \delta$ T-sejtek aránya, míg a bronchoalveolaris folyadékban fokozódott az inaktivált $\gamma \delta$ T-sejtek mennyisége $[45,46]$.

A mikrobiális fertőzésekkel szembeni védelem mellett a $\gamma \delta$ T-sejtek IL-4-termelésük révén elősegítik a Th2-típusú immunválaszokat és eosinophilbeáramlást, valamint IFN $\gamma$-termelésük révén az IL-10-termelő Treg-sejteket is gátolják. Ugyanakkor IL-17A-termelésük miatt a pulmonalis $\gamma \delta \mathrm{T}$-sejtek gátolhatják is a Th2-típusú allergiás reakciót, amit az ILC2-sejtek is korlátozhatnak.

A barrierfelületek immunológiai védelmében részt vevő, IL-17-termelő lymphocyták legnagyobb részét a $\mathrm{CD} 4^{+}$T-sejtek egyik alcsoportja (Th17) alkotja. A Thl7 $\mathrm{CD}^{+}{ }^{+}$T-sejtek TGFß és IL-6-citokinek hatására alakulnak ki. Emellett a naiv CD4+ ${ }^{+}$-sejtek aril-hidrokarbonreceptorának (Ahr) ligandkötése (például a cigarettafüst aromás vegyületei) és egyéb citokinek (IL-1 $\beta$, IL-23) is elősegíthetik a Th17 irányú CD4+ ${ }^{+}$T-sejt-differenciálódást. IL-17 hiányában (vagy az IL-17-receptor elégtelen szignálfunkciójának következtében) chronicus mucocutan candidiasis (CMC) alakul ki. Cystás fibrosisban az IL-17-hatás gátlása csökkentette a tüdőben zajló gyulladást, míg a fokozott IL-17-receptor-szignalizáció fokozott emphysemahajlamot váltott ki, és a kórképben megfigyelt iBALT-képződés mértéke is fokozódott, feltehetően az IL-17 által a tüdő parenchymájában indukált B-sejt-kemoattraktáns CXCL13 termelődése révén [45].

A tüdó és a mediastinalis nyirokcsomó naiv/memória $\mathrm{CD} 4^{+}$T-sejt összetétele sejtfelszíni fenotípusuk alapján hasonló, és in vivo osztódási jellemzőik is megegyeznek. A naiv $\mathrm{CD}^{+}{ }^{+}$T-sejtek eljutása a véráramból a tüdőbe jelentős részben független az L-szelektintől (CD62L), valamint a pertussistoxin-érzékeny kemokinreceptoroktól (elsősorban a CCR7-től és CCL19/21 ligandjaiktól), míg a tüdőből való kilépésük független az (FTY720 által blokkolható) S1P felismeréstől/gradienstől. Ezekkel ellentétben a CD4 ${ }^{+}$T-sejteknek a tüdőből a mediastinalis nyirokcsomóba való továbbjutása CCR7-függő, és ez az 
áthelyeződés szükséges az antigénreaktív T-sejtek aktiválódásához és az immunválaszban való részvételükhez is [47].

Antigénfelismerésüket követően az $\alpha \beta$-láncokból álló, TcR-hordozó, naiv CD4+ ${ }^{+}$T-sejtek számos irányban differenciálódhatnak, ezáltal központi szerepet töltenek be a veleszületett immunvédelem sejtjeinek, a $\mathrm{CD}^{+} \mathrm{T}$ - és B-sejteknek, valamint az egyéb CD4+ T-sejteknek a szabályozásában. Ezek elkülönítése számos sejtfelszíni citokin- és kemokinreceptor, adhéziós molekula és addreszszinreceptor, valamint intracelluláris citokinek és transzkripciós faktorok egyidejü kimutatásával lehetséges. A nem lymphoid szövetekben (így például a tüdőben) elhelyezkedő memória-T-sejtek túlnyomó része a szövetrezidens memóriacsoportba tartozik $\left(\mathrm{T}_{\mathrm{RM}}\right)$.

A tüdő $\mathrm{T}_{\mathrm{RM}} \mathrm{CD}^{+}{ }^{+} \mathrm{T}$-sejtek a vírusfertőzésekkel szemben nyújtanak védelmet; szintén IL-2 (és IL-15) jelenlétében alakulnak ki antigénstimuláció hatására, és jellemző rájuk a CD69-molekula jelenléte. Ugyanakkor az asztmás és más allergiás állapotokban kialakult pulmonalis $\mathrm{CD}^{+} \mathrm{T}_{\mathrm{RM}^{-}}$-sejteken a CD69-aktivációs marker általában nem mutatható ki [48].

Légúti vírusfertőzés után három $\mathrm{CD}^{+}$T-sejtes memóriasejt-populáció jön létre. Ezek közül a centrális memória-T-sejtek $\left(\mathrm{T}_{\mathrm{CM}}\right)$ a szekunder nyirokszövetekben halmozódnak fel, az effektor memória-T-sejtek $\left(\mathrm{T}_{\mathrm{EM}}\right)$ a véráram útján a különböző potenciális célszervek között recirkulálnak, míg a rezidens memória-T-sejtek $\left(\mathrm{T}_{\mathrm{RM}}\right) \mathrm{az}$ antigénbehatás színteréül szolgáló szövetben helyezkednek el [49]. A tüdőben a $T_{R_{M}}$-csoportot a (1) kevésbé citolitikus alveolaris és a (2) hatékonyabb interstitialis $\mathrm{T}_{\mathrm{RM}}$-sejtek alkotják, melyek kialakulásában és stabil perzisztenciájában a pulmonalis szövetkörnyezetben bekövetkező antigénexpozíciónak van kulcsszerepe [50]. Ennek során TGFß hatására fokozódik a CD69 és CD103, valamint a VLAl-molekula CD49a-integrinalegységének kifejeződése, míg a CCR7 és az SIPRI kifejeződése csökken, ezáltal elősegítve a $\mathrm{T}_{\mathrm{RM}}$-sejtek nem nyirokszöveti felszaporodását. A bronchiolaris hám által képzett CXCL16-kemokin a CXCR6-receptoron keresztül irányítja a $\mathrm{CD}^{+} \mathrm{T}_{\mathrm{RM}}$-sejtek elhelyezkedését a légutak mentén. A $\mathrm{T}_{\mathrm{RM}}$-sejtek közül az alveolaris $\mathrm{T}_{\mathrm{RM} \text {-alcsoport }}$ gyorsabban, az interstitialis $\mathrm{T}_{\mathrm{RM}}$-sejtek kissé lassabban eliminálódnak. Ezzel ellentétben a $\mathrm{CD}^{+} \mathrm{T}_{\mathrm{EM}^{-}}$-sejtek a helyi gyulladásindukciót követően csak átmenetileg mutathatók ki a légutakban [50].

\section{Következtetések, perspektívák}

Különleges szöveti szerveződésük, sejtösszetételük és felületük mérete miatt a légutak immunológiai védelme a kórokozókkal és allergénekkel szemben kiemelkedő jelentőséggel bír. Az itt elhelyezkedő immunkompetens sejtek komplex szerveződésű nyirokszövet-formációkat alakíthatnak ki, valamint a vér- és nyirokkeringés révén eljuthatnak más nyirokszövetbe is, ugyanakkor számos összetevő rezidens szövetalkotókkal, illetve a pleuralis mikrokörnyezettel áll szorosabb kapcsolatban, ami akadályozhatja részletesebb vizsgálatukat. A celluláris immunológiai, genetikai, bioinformatikai, valamint állatkísérletes módszertani fejlődés eredményeképpen a tüdő immunkompetens összetevőire és a múködésüket befolyásoló, nem haematopoeticus parenchymára vonatkozó ismereteink bővülése elősegítheti a tüdőspecifikus immunológiai folyamatok jobb megértését, és hozzájárulhat hatékonyabb megelőző (például vakcinációs) és terápiás eljárások kidolgozásához is. A további új ismeretek a régebb óta ismert és kutatott hiperszenzitív tüdőgyógyászati kórképek mellett bővíthetik a szisztémás autoimmun megbetegedések és az újonnan megjelenő, változó lefolyású és ismeretlen immunpatogenezisű (így a SARSCoV-2 okozta) fertőzések helyi és szisztémás immunológiai összetevőinek vizsgálati spektrumát, és elősegíthetik meglévő gyógykezelésük újraértékelését is.

Anyagi támogatás: A közlemény a 2020-4.1.1-TKP2020 Tématerületi Kiválósági Program 2020 intézményi kiválóság alprogram támogatásával készült.

A szerző a cikk végleges változatát elolvasta és jóváhagyta.

Érdekeltségek: A szerzőnek nincsenek érdekeltségei.

\section{Irodalom}

[1] Leiva-Juárez MM, Kolls JK, Evans SE. Lung epithelial cells: therapeutically inducible effectors of antimicrobial defense. Mucosal Immunol. 2018; 11: 21-34.

[2] Smole U, Kratzer B, Pickl WF. Soluble pattern recognition molecules: guardians and regulators of homeostasis at airway mucosal surfaces. Eur J Immunol. 2020; 50: 624-642.

[3] Cunha C, Aversa F, Lacerda JF, et al. Genetic PTX3 deficiency and aspergillosis in stem-cell transplantation. $\mathrm{N}$ Engl J Med. 2014; 370: 421-432.

[4] Kabbani D, Bhaskaran A, Singer LG, et al. Pentraxin 3 levels in bronchoalveolar lavage fluid of lung transplant recipients with invasive aspergillosis. J Heart Lung Transplant. 2017; 36: 973979.

[5] Sproston NR, Ashworth JJ. Role of C-reactive protein at sites of inflammation and infection. Front Immunol. 2018; 9: 754. https://doi.org/10.3389/fimmu.2018.00754

[6] Ogden CA, deCathelineau A, Hoffmann PR, et al. Clq and mannose binding lectin engagement of cell surface calreticulin and CD91 initiates macropinocytosis and uptake of apoptotic cells. J Exp Med. 2001; 194: 781-95.

[7] Tacnet-Delorme P, Gabillet J, Chatfield S, et al. Proteinase 3 interferes with $\mathrm{Clq}$-mediated clearance of apoptotic cells. Front Immunol. 2018; 9: 818. https://doi.org/10.3389/fimmu.2018.00818

[8] Kopf M, Schneider C, Nobs SP. The development and function of lung-resident macrophages and dendritic cells. Nat Immunol. 2015; 16: 36-44.

[9] Schneider C, Nobs SP, Kurrer M, et al. Induction of the nuclear receptor PPAR $-\gamma$ by the cytokine GM-CSF is critical for the differentiation of fetal monocytes into alveolar macrophages. Nat Immunol. 2014; 15: 1026-1037.

[10] Guilliams M, De Kleer I, Henri S, et al. Alveolar macrophages develop from fetal monocytes that differentiate into long-lived 
cells in the first week of life via GM-CSF. J Exp Med. 2013; 210: 1977-1992.

[11] Minutti CM, Modak RV, Macdonald F, et al. A macrophagepericyte axis directs tissue restoration via amphiregulin-induced transforming growth factor beta activation. Immunity $2019 ; 50$ : 645-654.e6.

[12] Zilionis R, Engblom C, Pfirschke C, et al. Single-cell transcriptomics of human and mouse lung cancers reveals conserved myeloid populations across individuals and species. Immunity 2019; 50: 1317-1334.el0.

[13] Terry PB, Traystman RJ. The clinical significance of collateral ventilation. Ann Am Thorac Soc. 2016; 13: 2251-2257.

[14] Neupane AS, Willson M, Chojnacki AK, et al. Patrolling alveolar macrophages conceal bacteria from the immune system to maintain homeostasis. Cell 2020; 183: 110-125.el1.

[15] Evren E, Ringqvist E, Willinger T. Origin and ontogeny of lung macrophages: from mice to humans. Immunology $2020 ; 160$ 126-138.

[16] Ural BB, Yeung ST, Damani-Yokota P, et al. Identification of a nerve-associated, lung-resident interstitial macrophage subset with distinct localization and immunoregulatory properties. Sci Immunol. 2020; 5: eaax8756. https://doi.org/10.1126/sciimmunol.aax 8756

[17] Bal SM, Golebski K, Spits H. Plasticity of innate lymphoid cell subsets. Nat Rev Immunol. 2020; 20: 552-565.

[18] Manickam C, Sugawara S, Reeves RK. Friends or foes? The knowns and unknowns of natural killer cell biology in COVID-19 and other coronaviruses in July 2020. PLoS Pathog. 2020; 16: el008820. https://doi.org/10.1371/journal.ppat.1008820

[19] Kabata H, Moro K, Koyasu S. The group 2 innate lymphoid cell (ILC2) regulatory network and its underlying mechanisms. Immunol Rev. 2018; 286: 37-52.

[20] Symowski C, Voehringer D. Th2 cell-derived IL-4/IL-13 promote ILC2 accumulation in the lung by ILC2-intrinsic STAT6 signaling in mice. Eur J Immunol. 2019; 49: 1421-1432.

[21] Fali T, Aychek T, Ferhat M, et al. Metabolic regulation by PPAR $\gamma$ is required for IL-33-mediated activation of ILC2s in lung and adipose tissue. Mucosal Immunol. 2021; 14: 585-593. https:// doi.org/10.1038/s41385-020-00351-w

[22] Halim TY, Rana BM, Walker JA, et al. Tissue-restricted adaptive type 2 immunity is orchestrated by expression of the costimula tory molecule OX40L on group 2 innate lymphoid cells. Immunity 2018; 48: 1195-1207.e6.

[23] Wang S, Xia P, Chen Y, et al. Regulatory innate lymphoid cells control innate intestinal inflammation. Cell 2017; 171: 201216.el8.

[24] Sui P, Wiesner DL, Xu J, et al. Pulmonary neuroendocrine cells amplify allergic asthma responses. Science 2018; 360: eaan8546. doi: $10.1126 /$ science.ann 8546

[25] Nagashima H, Mahlakõiv T, Shih HY, et al. Neuropeptide CGRP limits group 2 innate lymphoid cell responses and constrains type 2 inflammation. Immunity 2019; 51: 682-695.e6.

[26] Moriyama S, Brestoff JR, Flamar AL, et al. $\beta_{2}$-Adrenergic receptor-mediated negative regulation of group 2 innate lymphoid cell responses. Science 2018; 359: 1056-1061.

[27] Morita H, Kubo T, Rückert B, et al. Induction of human regulatory innate lymphoid cells from group 2 innate lymphoid cells by retinoic acid. J Allergy Clin Immunol. 2019; 143: 2190-2201. e9.

[28] Cephus JY, Stier MT, Fuseini H, et al. Testosterone attenuates group 2 innate lymphoid cell-mediated airway inflammation. Cell Rep. 2017; 21 : 2487-2499.

[29] Hwang JY, Randall TD, Silva-Sanchez A. Inducible bronchusassociated lymphoid tissue: taming inflammation in the lung. Front Immunol. 2016; 7: 258. https://doi.org/10.3389/fimmu. 2016.00258
[30] Silva-Sanchez A, Randall TD. Role of iBALT in respiratory immunity. Curr Top Microbiol Immunol. 2020; 426: 21-43.

[31] Reed HO, Wang L, Sonett J, et al. Lymphatic impairment leads to pulmonary tertiary lymphoid organ formation and alveolar damage. J Clin Invest. 2019; 129: 2514-2526.

[32] Rangel-Moreno J, Carragher DM, de la Luz Garcia-Hernandez $\mathrm{M}$, et al. The development of inducible bronchus-associated lymphoid tissue depends on IL-17. Nat Immunol. 2011; 12: 639646.

[33] Fleige H, Ravens S, Moschovakis GL, et al. IL-17-induced CXCL12 recruits B cells and induces follicle formation in BALT in the absence of differentiated FDCs. J Exp Med. 2014; 211 : 643-651.

[34] Moyron-Quiroz JE, Rangel-Moreno J, Kusser K, et al. Role of inducible bronchus associated lymphoid tissue (iBALT) in respiratory immunity. Nat Med. 2004; 10: 927-934.

[35] Marin ND, Dunlap MD, Kaushal D, et al. Friend or foe: the protective and pathological roles of inducible bronchus-associated lymphoid tissue in pulmonary diseases. J Immunol. 2019; 202: 2519-2526.

[36] Yoshimoto M. The ontogeny of murine B-la cells. Int J Hematol. 2020; 111: 622-627.

[37] Lábadi A, Balogh P. Differential preferences in serosal homing and distribution of peritoneal B-cell subsets revealed by in situ CFSE labeling. Int Immunol. 2009; 21: 1047-1056.

[38] Moro K, Yamada $\mathrm{T}$, Tanabe $\mathrm{M}$, et al. Innate production of $\mathrm{T}(\mathrm{H}) 2$ cytokines by adipose tissue-associated c-Kit $(+) \mathrm{Sca}-\mathrm{I}(+)$ lymphoid cells. Nature 2010; 463: 540-544.

[39] Jackson-Jones LH, Duncan SM, Magalhaes MS, et al. Fat-associated lymphoid clusters control local IgM secretion during pleural infection and lung inflammation. Nat Commun. 2016; 7: 12651. https://doi.org/10.1038/ncomms12651

[40] Waffarn EE, Hastey CJ, Dixit N, et al. Infection-induced type I interferons activate CDllb on B-l cells for subsequent lymph node accumulation. Nat Commun. 2015; 6: 8991. https://doi. org /10.1038/ncomms9991

[41] Weber GF, Chousterman BG, Hilgendorf I, et al. Pleural innate response activator $\mathrm{B}$ cells protect against pneumonia via a GMCSF-IgM axis. J Exp Med. 2014; 211: 1243-1256.

[42] Blandino R, Baumgarth N. Secreted IgM: new tricks for an old molecule. J Leukoc Biol. 2019; 106: 1021-1034.

[43] Allie SR, Bradley JE, Mudunuru U, et al. The establishment of resident memory $\mathrm{B}$ cells in the lung requires local antigen encounter. Nat Immunol. 2019; 20: 97-108.

[44] Cheng M, Hu S. Lung-resident $\gamma \delta \mathrm{T}$ cells and their roles in lung diseases. Immunology 2017; 151: 375-384.

[45] Iwanaga N, Kolls JK. Updates on T helper type 17 immunity in respiratory disease. Immunology 2019; 156: 3-8

[46] Peng MY, Wang ZH, Yao CY, et al. Interleukin 17-producing gamma delta $\mathrm{T}$ cells increased in patients with active pulmonary tuberculosis. Cell Mol Immunol. 2008; 5: 203-208.

[47] Caucheteux SM, Torabi-Parizi P, Paul WE. Analysis of naïve lung CD4 T cells provides evidence of functional lung to lymph node migration. Proc Natl Acad Sci USA 2013; 110: 1821-1826.

[48] Nguyen QP, Deng TZ, Witherden DA, et al. Origins of CD4 ${ }^{+}$ circulating and tissue-resident memory T-cells. Immunology 2019; 157: 3-12.

[49] McMaster SR, Wein AN, Dunbar PR, et al. Pulmonary antigen encounter regulates the establishment of tissue-resident CD8 memory $\mathrm{T}$ cells in the lung airways and parenchyma. Mucosal Immunol. 2018; 11: 1071-1078.

[50] Hayward SL, Scharer CD, Cartwright EK, et al. Environmental cues regulate epigenetic reprogramming of airway-resident memory CD8 ${ }^{+} \mathrm{T}$ cells. Nat Immunol. 2020; 21: 309-320.

(Balogh Péter dr., Pécs, Ifjúság útja 20., 7624 e-mail: balogh.peter@pte.hu)

A cikk a Creative Commons Attribution 4.0 International License (https://creativecommons.org/licenses/by/4.0/) feltételei szerint publikált Open Access közlemény. (SID_1) 